\title{
Dissolution AND APOTheOSIS OF THE QUEER BODY IN THE LAZARUS HEART, By The Trans author Poppy Z. Brite
}

\author{
A dissolução e a apoteose do corpo queer em \\ The Lazarus Heart, do autor trans Poppy Z. Brite
}

\author{
ANDRIO J. R. Dos SANTOS ${ }^{1}$ \\ ${ }^{1}$ Universidade Federal de Santa Maria, Santa Maria, RS, Brasil \\ E-mail: andriosantoscontato@hotmail.com
}

\begin{abstract}
In The Lazarus Heart, the trans author Poppy Z. Brite sets a brutal anatomy of gender and sexuality, and examines the violence and abjection frequently imposed on queer subjects, especially on trans people. Body, gender, and sexuality occupy a central role in the novel, which allows Brite's work to be read as queer Gothic, a type of fiction understood as an interstice between Gothic studies and queer studies. Berenice Bento states that transsexual bodies are fabrications engendered by particular technologies, and Butler defines gender as performance; these are the central issues to the analysis I propose here. My main goal is to discuss the thematic development towards the body. I pay particular attention to the violence inflicted upon, as well as the restoration of the body, also observing the character development of Lucrece.
\end{abstract}

EDITOR-CHEFE:

Gerson Roberto Neumann

EDITOR EXECUTIVO:

Regina Zilberman

KEYWORDS: queer gothic; queer studies; trans; gender; criticism.

\section{RESUMO}

Em The Lazarus Heart, o autor trans Poppy Z. Brite realiza uma brutal anatomia do gênero e da sexualidade, examinando a violência e abjeção imposta a indivíduos queer, em particular a pessoas trans. Corpo, gênero e sexualidade ocupam papel central na obra do autor, o que permite que sua obra seja lida a partir do escopo do gótico queer, um interstício entre os estudos do gótico e os estudos queer. Berenice Bento comenta que corpos transexuais são fabricações geradas por tecnologias específicas, ao passo que Judith Butler define gênero como performance, duas questões centrais à análise que proponho no presente ensaio. Meu objeto é discutir o desenvolvimento do tema do corpo no romance de Brite, atendo-me à violência infligida e à restituição do corpo, assim como ao desenvolvimento da personagem Lucrece.

PALAVRAS-CHAVE: gótico queer; estudos queer; trans; gênero; crítica.

SANTOS, Andrio J. R. dos. Dissolution and apotheosis of the queer body in The Lazarus Heart, by the trans author Poppy Z. Brite. Revista Brasileira de Literatura Comparada, v. 23 , n. 44 , p. $90-99$, set.dez., 2021. doi: https:// doi.org/10.1590/2596$304 \times 20212344 a j r s$ 


\section{INTRODUCTION}

Susan Stryker (2008) remarks on the importance of integrating trans experience into fiction, which not necessarily reduces a study to some sort of biographical speculation-a source of anxieties throughout Brazilian literary studies. What the author is actually referring to is the articulation of the subject's experience with the source material that underlies and originates fiction. In other words, we are approaching the work of authors who "write about what they know," which is a common saying in the North American publishing market. This is the way I'm reading the queer Gothic fiction produced by the trans author Poppy Z. Brite. Hughes and Smith (2009) had already observed that, before transitioning, Brite had worked as a stripper on the north and less mainstream side of New Orleans. This experience had been articulated in terms of character development towards Eddie, one of Drawing Blood (1993) central figures.

Hughes and Smith comment that "Brite herself is queer, and with a queerness that far exceeds the specific homosexual content that has seen her work applauded by an aware gay readership" (2009, p. 3); such remark suggests that Brite can't be detached from queer performance and style both as an author and as a subject, and those instances converge in his criticism against compulsory heteronormativity (We should take notice the authors refer to Brite by a feminine noun, which I will be approaching soon). Brite's persona, as an author, is inseparable from his work. In this sense, "Queer, like Gothic (and, for Brite, like Goth also), is both performance and style, and the very nature of this process means that it will exist in a tense space between referential association with the normative and absolute separation from its morals and aesthetics" (HUGHES; SMITH, 2009, p. 4). Of course, we are not addressing fiction as the author's biographical self-expression, neither take for granted that everything regarding the author's work is related to his experience. Yet, it's an issue pertinent enough to be taken into account. After all, the centrality of a queer identity as well as the particular interest towards body, gender, and sexuality is what allows us to address Brite's fiction as queer Gothic. Besides, Brite himself is a trans man, and this is something we need to address, especially because it's an identity feature frequently ignored by scholars.

Poppy Z. Brite identifies himself as a gay man since his youth. In his essay Enough Rope, first published in Crossing the Border: Tales of Erotic Ambiguity (1998), the author comments that "[e]ver since I was old enough to know what gay men were, I’ve considered myself a gay man that happens to have been born in a female body" (BRITE, 1998, p.1). In an interview for Vice, published in 2007 on the magazine's website, Brite remarks that "I identify as male, and as gay. Some people would call me a non-operative transsexual, since I've never made any attempt to transition or even to appear male" (BRITE, 2007). Between mid 2010 and 2012, the author underwent a gender reassignment process, taking on the name of Billy Martin, although the transition dates are not that simple to delineate. Despite changing his name, he continues to sign his fiction as Poppy Z. Brite. On several occasions, the author has commented that he bases his fiction on obsessions and personal issues, which sheds light on his queer, gay, and bisexual characters who integrate marginal subcultures, particularly Goth Subculture.

However, there's a discrepancy on academic criticism regarding the fact that Brite is a gay trans man. Brite is mentioned as a female author in the following texts: the chapter "Female Vampirism", from Women and the Gothic (2016); the chapter "Contemporary Woman's Gothic", from A Companion 
to American Gothic (2014); and the chapter "Love Bites: Contemporary Women's Vampire Fictions", from A New Companion to the Gothic (2012), among others. William Hughes adds the following observation to the entry on Brite in his Historical Dictionary of Gothic Literature: "Rumors regarding Brite having adopted the name Billy Martin on becoming a transgender male in the first decade of the 21 st century were not, at the time of writing, confirmed by the author's own website" (2013, p. 45).

Hughes mentions that Brite's gender transition couldn't be confirmed on his website, which exists, according to its registration information, since the 2000s. Such observation suggests that Brite hadn't published anything about it on his website yet, and perhaps not even had published Enough Rope on the platform. Today, the essay can be found on his portal, even though the text was initially published in a collection in 1998. However, this addendum, whose purpose perhaps was to demonstrate attentiveness towards the author's gender, complicates things further. Vice's interview in which Brite mentions the term "non-operative transsexual," as well as clarifies that he identifies himself as a gay man has been available since 2007. And I quoted just four recent examples from the past decade to illustrate such a problem.

It's worth mentioning that Brite had previously commented on how he identifies himself regarding gender since the first publication of Lost Souls, in 1992. Until 1998, he gave several interviews where he addresses the subject. In the mid 2000s he gave more interviews approaching even the distinction between his gender identity and his gender expression. And then we have another question: why the academic criticism towards Brite's fiction seems to ignore such basic information? A quick Google search for Poppy Z. Brite gives us old photos of the author, with clothes hegemonic considered feminine, in addition to his assigned name, Melissa Ann Brite. This could very well be the reason, but that is just speculation. The fact that Brite is mentioned as a female author in academic works approaching the Gothic, works that also approach feminism, gender, and queer studies, revels that even in this field the machinery of social institutions predicting that gender must always correspond to certain hegemonic images, concepts, and representations are fully operational. According to Stryker, some characteristics, called "Secondary sex," constitute "perhaps the most socially significant part of morphology—taken together, they are the bodily 'signs' that others read to guess at our sex, attribute gender to us, and assign us to the social category they understand to be most appropriate for us" (STRYKER, p. 34). I'm not mentioning this issue in order to make any accusations or to presume a solution, but to give visibility to something that often goes unnoticed.

Of course, Brite's work doesn't refer only to his experience, but ignoring such fact makes us miss part of the strength of his fiction as well as some essential features of his aesthetics; because his aesthetic is a queer aesthetic - a bodily, material, and sensory aesthetic. His aesthetic features the possibility of reintegrating the body not to a state of purity or prelapsarian state, but to an apotheosis of dissidence in terms of gender and sexuality. Berenice Bento comments that "transsexuals and non-transsexuals bodies are fabricated by specific and sophisticated technologies which the most powerful outcome is the production, into the subject's subjectivity, of the belief that the identity assignment is inscribed in some part of the body" (2017, p. 226). Brite explores such issues in The Lazarus Heart (1998). In this essay, my goal is to analyze how Brite develops certain issues toward the body; I also intend to analyze Lucrece in terms of character development under the scope of queer Gothic and queer studies. 


\section{THE SHATTERED BODY AND THE TRANS BODY RESTORED IN THE LAZARUS HEART}

The Lazarus Heart (1998) is part of the multimedia universe encompassing the cult graphic novel The Crow (1994), by James O’Barr. This fictional universe became best known for its cinematic sequence, which comprises The Crow (1994), The Crow: City of Angels (1996), The Crow: Salvation (2000), and The Crow: Wicked Prayer (2005). Among these, the first film achieved significant success; the second and the fourth production received a poor reception; the third film practically buried the franchise. The movie was poorly advertised and was available at a promotional price in department stores even before its release date, and it hasn't been released in theaters. The Crow: Salvation is loosely based on The Lazarus Heart, but besides some elements of plot, it bears no connection or resemblance to Brite's work. All queer elements had been taken off the production, and the story was completely twisted to fit heteronormative institutions.

The Lazarus Heart is set in New Orleans, and such setting grants a paradoxical aura to the story, mixing a dying and dark past with the effervescent multiculturalism by which the city is known. The plot follows the narrative of Jared Poe, a controversial photographer who explores themes related to BDSM and club culture. Jared was unjustly sentenced to death after being found guilty of murdering his boyfriend, Benny DuBois. He was then resurrected by the crow in order to find the responsible for the crime and to take revenge for the death of his lover. Here, we already have something interesting since Brite contradicts one of the most common narrative conventions in the universe of The Crow. In the graphic novel, Eric Draven is guided back from the underworld to avenge his bride's death. In The Lazarus Heart, Jared returns to avenge the death of his boyfriend. Brite makes revenge almost irrelevant since all forms of justice (earthly or unearthly) end up failing the characters. In addition, one of the most relevant characters is Lucrece, Benny's trans (and twin) sister, who assists Jared in his search and, as he fails, she takes on a leading role determinant to the narrative. Even though the queer aspect is already present, Brite makes not only the narrative queer, but also the heteronormative fictional cosmos of the original story. It's worth mentioning that there is a close relation between The Lazarus Heart and Edgar Allan Poe's works - the obvious tribute to Jared Poe surname, or the serial killer and antagonist who uses excerpts from the poem The Raven to mark crime scenes.

Anne Jones and Susan Donaldson make the following observation concerning body and sexuality and the American South, "[ $\mathrm{t}$ ]he stories of southern bodies have been structured in large part by interlocking logics of dichotomy — masculine and feminine, white and black, master and slave [...] that have characterized the dominant public written discourse of the South" $(1997, \mathrm{p}$. 2). This is an issue related to one of the defining features of Gothic fiction, namely, its ability to render or symbolize social anxieties. Gothic explores contradictions, dichotomies, and distortions, relating them to social constructions of meaning permeating history, society, and ideologies. Eric Savoy goes so far as to proclaim that "Gothic is the dark nightmare of the American Dream" (2002, p. 167).

Several themes and social forces converge in The Lazarus Heart-marginalized minorities, the hostile context of the compulsory heteronormativity, and the very panoply of political and social mechanisms that potentiate violence against queer subjects. Brite's narrative denounces the social system and southern beliefs. After the Civil Rights Movement of the mid 1950-60s, the American South took a new breath and entered the globalization era, which produced tensions between the local 
against the global. In other words, there's a sort of cultural dynamic deeply rooted into the regional cultural system, encoded in the slavery past, in the oligarchies decay, and in the idealized nostalgia for some sort of (imagined) southern Golden Age. Some authors raise the question of where would be the place to the marginal, to the queer, in this context. And such matters resonate directly to issues related to body, one of the main issues of Brite's novel.

The story begins with Jared Poe's resurrection at Lafayette Cemetery No 1 . Brite sets a vivid description of a shattered and ruined body being restored:

So much damage to a corpse after death, the slicing ministrations of pathologists and undertakers. Because this man died violently there was an autopsy, organs removed, divined, dumped back into their cold cradle of meat and bone. The application of glue to seal the eyelids and hold fingers together, lips sewn neatly shut, caustic chemicals painted on or pumped into this body [...]. (BRITE, 1998, p. 4)

The medical interventions described has an invasive tone suggested by "the slicing ministrations of pathologists"; interestingly, while the embalming process is described as a crude, practical and antiseptic process, we see a mystical element concerning the removal of the organs: Brite uses the term "divined," which refers both to prognosis and divination-the well-known trope of the oracle who predicts fate by reading the viscera. The organs are then putted back into their "cold cradle of meat and bone". The image of the body as a receptacle of flesh refers to the notion of the body as a transitory form that accommodates an identity under construction; Lucrece becomes a woman when performing a gender, and later her relationship with BDSM subculture echoes Butler's (1990) concept of body stylization. This process of becoming, paralleled to this view of the body as a construction open to exterior modifications and constant transformations, suggests that the identity of Brite's characters has a performative basis. In addition, the image of human intervention ("application of glue"; "lips sewn") demonstrates the malleability of the body.

As the scene unfolds, the crow caws darkly, and the body responds contracting, being engulfed in life, regenerating itself from the state of death:

The thread that holds the dead man's thin lips closed tugs free, drawn out through needlepoint incisions, and falls away [...]. The long incisions in the abdomen reject their stitches also and begin to heal, flesh knitting as if in timelapse photography [...]. Still more stitches ravel, and the body bleeds not blood but an acrid hemorrhage of embalming fluid, milky spray from opened arteries. The heart is shocked rudely back to life, pumping alien liquid through desiccated veins, and this time the crow does not caw, she screams as the body beneath her expels four gallons of embalming fluid into its coffin. A pulsing stream from the carotid, from an incision in the upper arm and another in the groin, until the circulatory system is completely empty, purged, and the Lazarus heart pumps only formaldehyde-stinking air. (BRITE, 1998, p. 4-5)

The excerpt suggests an inversion of an antiseptic notion. The body re-enters the cycle of life as it nullifies embalming changes and reverts the medical procedures that turned it into a corpse suitable for a public funeral_ "The thread that holds the dead man's thin lips closed tugs free"; "incisions in the abdomen reject their stitches". It's interesting to note that "the body bleeds not blood but an acrid hemorrhage of embalming fluid," and that " $[\mathrm{t}]$ he heart is shocked rudely back to life, pumping alien liquid through desiccated veins," which suggests that Jared's and Lucrece's rebirth (which occurs at the end of the novel) indicates that the queer subject, in Brite's fiction, is like an individual who has 
been reborn, who has resurfaced from a kind of death-death in a more social sense considering the hegemonic discourses. Such process is similar to what Kristeva comments on abjection:

The abject shatters the wall of repression and its judgments. It takes the ego back to its source on the abominable limits from which, in order to be, the ego has broken away-it assigns it a source in the non-ego, drive, and death. Abjection is a resurrection that has gone through death (of the ego). It is an alchemy that transforms death drive into a start of life, of new signifiance. The abject is related to perversion. (1985, p. 15)

The body is the main issue addressed in the novel; in particular, the trans body and the violence imposed upon trans bodies. Brite writes a transphobic serial killer, making use of gore images to develop the character. The serial killer represents the force of the (supposed) heteronormative purity exerted upon every gender and sexual dissidence. The novel introduces the murderer as an embodiment of purging, and also as a self-contradictory figure:

Sometimes, like tonight, the man in the big house by the river calls himself Jordan. There is a river called Jordan in the Bible, and he likes the names of rivers. Sometimes he calls himself Joseph Lethe, for another river and what it means, and sometimes he's Stanley Hudson. But these are secret names that he never tells anyone - except those few he'd chosen. Those he's sure will never be in a position to spread the word, to give away his names carelessly, like telephone numbers on filthy fag-bar rest room walls. (BRITE, 1998, p. 7)

Later, we learn that the killer had been striking by an electric shock produced by a lightning bolt, which caused him amnesia, and made him forget his name: "But the lightning had left something inside his head, and he couldn't remember his name. He knew other things, though. New things the lightning had wanted him to know. But not his name" (BRITE, 1998, p. 73). From that point on, which for him has the value of a mystical revelation, his sole purpose is to purge the city of New Orleans from what he understands as an infestation of trans people and anyone who "exhibit at least the behavioral symptoms of gender transgression" (BRITE, 1998, p. 74).

The killer dehumanizes trans people by referring to them in the third person, "it," which is usually only used for objects. At first glance, "the names of rivers" symbolizes the inevitable ebb and flow of nature and the purifying power of the aquatic element. However, this name changing aspect of the character also suggest a form of sublimation of his aversion to trans subjects since he needs to change his name to commit the crimes (as if his name was an essential and stable identity). Thus, the character disassociates some of his names (or identities) from the crimes he commits, compartmentalizing the horror; from the killer's perspective, this alternation of names and identities would ensure that he remains immune to the "infestation" he believes to be fighting.

Brite carries out a brutal and violent anatomy of gender and sexuality by narrating part of the story through the killer's point of view. The killer chooses his victims among trans people or crossdressers, women in particular. Each one of his victims is examined and dismembered on a surgical table because the murderer wishes to discover the "transgressive element" which transforms a person into "it"- a process resulting in the violent and painful death of the victims.

Michele is a transgender girl, member of a group of prostitutes from Jackson Square, and the scene portraying her torture and subsequent murder serves as an example. The killer asks her about 
what had happened on July 2, 1947, the day he had been striking by an electrical shock caused by a lightning bolt. As we read, "Michele wakes up in a place that smells disinfectant and mold and latex. He's lying on a bare metal table and there's insane light, white and blinding light that stabs at his eyes and makes his head hurt even worse" (BRITE, 1998, p. 32). The passage is narrated from the murderer's point of view, who doesn't recognize Michele's gender identification, something he expresses by the recurrent use of the masculine noun "he".

The killer puts himself in a position of power, of total control, in order to display and explore her trans body: "Growling, the man lunges into the glare of the surgical light so that its glow crowns his head like a mad saint's nimbus. He seizes Michele's face in both his huge, clammy hands, one for either side, his thumbs poised above Michele's eyes like snakes readying to strike" (BRITE, 1998, p. 33). Finally, the killer "is filling a syringe with a clear liquid. He plunges the needle into the exposed muscles of Michele's abdomen, and The Pain lunges forward one last time. The sound of its claws and the crumbling stone are very loud, drowning the raw world of meat and steel" (BRITE, 1998, p. 38). The killer needs to dissect and literally to empty the trans body out of all organs in order to destroy the meaning of the transgressive body. As Patricia Yaeger (2005) observes, the symbolic meaning is intertwined with the subject's body in such a way that only the dissolution of the body can cause the symbolic meaning to be erased.

However, the plot conclusion brings a twist concerning the trans body. Lucrece is the one who suffers the most, physically and psychologically. Still, she emerges victorious, overcoming the suffocating cloud of pain and injustice that hangs over the novel's fictional world. Lucrece is presented in flashback, years before her gender reassignment surgery. Lucrece had grown up (during childhood using the name Lucas) alongside her brother, under the care of their wealthy and eccentric aunt, Isolde. She identifies herself as queer from a very young age, and added to the fact that " $[\mathrm{h}]$ ow unnatural it was for two boys to be raised by an old spinster lady in her creepy old house" (BRITE, 1998, p. 10), Lucrece and her brother were bullied and assaulted by their neighbors, particularly when "the twins were walking quickly along the red-dust road that connected their house with the rest of the town, other children would hide in the bushes and throw rocks or dried-up cow pies at them, calling them sissies and weirdoes" (BRITE, 1998, p. 11).

At the novel's conclusion, the killer captures Lucrece. He admits that his initial plan was to have captured and murdered her instead of her brother Benny. Lucrece had already demonstrated psychic abilities, and she connects her mind with the killer's hoping to purify his mind: "[w] hen her mind brushes against his, she screams. There's something coiled deep inside his skull, a serpent made of fire" (BRITE, 1998, p. 75). However, as the killer feels violated by the connection with Lucrece, he reaffirms his dominance: "I am the conduit for all that is pure, and you have polluted me" (BRITE, 1998, p. 76). Thus, he decides to treat Lucrece, this "thing" (it), differently from his other victims: he chooses to rape her as revenge. Afterwards, we see Lucrece's body during the final scene when Jared confronts the killer. Detective Frank Gray finds the character's body, which is described in horrendous excess:

The corpse's bloodless legs are spread out in a wide V, each ankle bound with white nylon cord that has been tied securely through iron eyes in the floor. The body has been completely eviscerated, slit from the genitals all the way up to the chin, and the blood-drenched floor beneath it is scattered with discarded organs and entrails, bluish loops of intestine and darker, meaty lumps he can't identify. The 
abdominal cavity is empty, a hollowed-out shell of muscle and cartilage and bone [...]. It's impossible for him to tell if the corpse is male or female. (BRITE, 1998, p. 80)

Brite doesn't show us the act of murder, but his Gothic machinery illustrates the visceral horror of the scene. At that moment, the murderer's victory seems indubitable, especially because the description of Lucrece's mutilated body suggests the erasure of her gender: "It's impossible for him to tell if the corpse is male or female". In other words, the killer would have fulfilled his purpose of destroying her in such a way that there would be no recognizable identity left. This would be Lucrece's defeat since her identity as a trans woman would have been erased.

Now that Lucrece has been devoid of life, Brite makes use of the latent mystical element in the character's development to bring her back to life triumphantly. In the first chapter, the crow brought Jared back to life, but as he loses his purpose by his confusion and anguish towards his own death, he fails to fulfill the divine task of vengeance assigned to him. Therefore, when Lucrece dies, she encounters a flock of crows led by "a crow so black, so impossibly enormous that he might have been the very first, the incarnation of age clothed in ragged black feathers" (BRITE, 1998, p. 84). Then, the character is reborn:

Lucrece raises her head and opens her eyes, and the man who calls himself by the names of rivers fills his lungs and screams again and again. The knots he tied so carefully are unraveling and the ropes are ripping loose, snapping like sewing thread. In another moment her hands and ankles are free and she drops to the floor [...]. The blood itself flows backward, pours over the rims of the buckets and flows like retreating red tide across the floor. It all rises as if suspended on invisible wires, a puppet show for ghouls. Everything the man has taken from her, every bit of flesh and every drop of spilled blood, becomes a swirling, living cloud, rushing to refill the empty cavity of Lucrece's body. (1998, p. 84)

Lucrece's rebirth paralleled the first scene of the novel, when Jared is reborn. However, instead of medical procedures and embalming fluids, it's the killer's violent acts that are purged from her body: " $\mathrm{t}]$ he knots he tied so carefully are unraveling and the ropes are ripping loose," and "her hands and ankles are free". In addition, while Jared's heart pumps formaldehyde, Lucrece's heart is filled with blood in a somewhat gore image: " $\mathrm{t}]$ he blood itself flows backward", and "flows like retreating red tide". The "red tide" reallocates Lucrece's body into the cycle of life. However, instead of the antiseptic tone as in Jared's resurrection, Lucrece's rebirth is something organic and has a naturalizing value: "[e] verything the man has taken from her, every bit of flesh and every drop of spilled blood, becomes a swirling, living cloud, rushing to refill the empty cavity of Lucrece's body". Her mutilated body goes back to its "original" state, which is Lucrece's body as a trans woman.

After that, the novel reaches its end as revenge waits in the corner; according to The Crow's lore, revenge makes up for an act wrongly perpetrated.

\section{FINAL REMARKS}

Lucrece is introduced as an outcast and gender dissident; as someone who has broken through pre-defined gender barriers, and who has been subsequently destroyed and reborn under a new aegis of meaning. Lucrece's body has been portrayed as something despised, feared, and vulnerable in relation to the hegemonic discourse. However, Brite reestablishes the character's body in a new meaning. 
Lucrece, who has been previously an object of abjection, becomes a subject of her own desires. Thus, Brite redefines a body hegemonic classified as horrendous as a body endowed with energy and life.

Brite not only reverts the violence suffered by Lucrece, the author actually reconstructs her body, and by doing so the narrative restores the character's lost subjectivity and sense of identity. Such process naturalize Lucrece's gender since she has been reborn in her "original" state, that is, as a trans woman. This reading highlights some specific issues often overlooked related to social habits and conventions. Of course, each particular body retains an aspect of difference and individuality. In that sense, it's what a subject does with their body, the stylization and practices that transforms their body and makes a person who they is. In addition, "[a]11 human bodies are modified bodies: they are bodies that diet and exercise, that get pierced and tattooed, whose feet get shaped by the kind of shoes they wear. Shaping, styling, and moving the body to present oneself to others [...]” (STRYKER, 2017, p. 31).

On the other hand, the same process demonstrates that bodies and identities are continuously under construction, and also denounces the abjection constantly imposed on trans people. This process as a whole brings into mind Butler's observations that the division between what is cultural (regarding gender) and what is presumed natural (regarding biological sex) doesn't quite have any solid grounds, once the body is not beyond the discourse and doesn't precede culture. In this sense, gender is inscribed on the body, and there's no essential subject. After all, an identity is always a constant construction produced by a performative act. As Bento states, "[the] transsexual body denounces that the matter which supports and sustain these norms is vulnerable, as it is fundamentally 'plastic', flexible, breaking the boundaries between culture (plastic) and nature (body)" (BENTO, 2017, p. 226-227).

\section{REFERENCES}

BENTO, Berenice. A Reinvenção do Corpo - Sexualidade e Gênero na Experiência Transexual. Salvador: Editora Devires, 2017.

BRITE, Poppy Z. Drawing Blood. New York: Random House, Inc: 1993.

BRITE, Poppy Z. Enough Rope. Available from: https://www.poppyzbrite.com/rope.html.

BRITE, Poppy Z. Enough Rope. In: TUTTLE, Lisa (Ed.). Crossing the Border: Tales of Erotic Ambiguity. London: Indigo, 1998.

BRITE, Poppy Z. The Larazus Heart. New York: Simon \& Schuster, 1998.

BUTLER, Judith. Gender Trouble - Feminism and Subversion of Identity (1990). New York: Routledge, 2002.

HUGHES, William. Historical dictionary of gothic literature. Plymouth, United Kingdom: Scarecrow Press, 2013.

HUGHES, William; SMITH, Andrew. Introduction. In: Queering the Gothic. Manchester: Manchester University Press, 2009.

JONES, Anne Goodwyn; DONALDSON, Susan Van D’Elden. Haunted Bodies: Gender and Southern Texts. Charlottesville: Virginia University Pess, 1997.

KELLNER, Amy. Poppy Z. Brite Is The King/queen Of New Orleans, Vice, November 30, 2007, 10:00pm. Available from: https://www.vice.com/en/article/avjvj5/poppy-z-bright-v14n12. 
KRISTEVA, Julia. Powers of Horror: An Essay on Abjection (1980). Trad: Leon Roudiez. New York: Columbia University Press, 1985.

O'BARR, James. The Crow (1994). New York: Gallery Books, 2011.

SAVOY, Eric. The Rise of American Gothic. In: HOGLE, Gerald E. (Ed.). The Cambridge Companion to Gothic Fiction. Cambridge: Cambridge University Press, 2002, p. 167-188.

STRYKER, Susan. Transgender history: the roots of today's revolution. Berkeley: Seal Press, 2017.

WISKER, Gina. Contemporary Women's Gothic: From Lost Souls to Twilight. In: CROW, Charles L. (Ed.). A companion to American gothic. Oxford: Wiley-Blackwell, 2014, p. 433-446.

WISKER, Gina. Female Vampirism. In: HORNER, Avril (Ed.); ZLOSNIK Sue (Ed.). Women and the Gothic - An Edinburgh Companion. Edinburgh: Edinburgh University Press Ltd, 2016, p. 150-168.

WISKER, Gina. Love Bites: Contemporary Women's Vampire Fictions. In: PUNTER, David (Ed.). New Companion to the Gothic. Oxford: Wiley-Blackwell, 2012, p. 224-238.

YAEGER, Patricia. Ghosts and Shattered Bodies, or What Does It Mean to Still Be Haunted by Southern Literature? In: South Central Review, Vol. 22, N. 1, 2005. Hopkins University Press, p. 87-108. 